S. Bulba

National Technical University «Kharkiv Polytechnic Institute», Kharkiv, Ukraine

\title{
COMPOSITE APPLICATION DISTRIBUTION METHODS MODELING
}

\begin{abstract}
The subject of consideration are algorithms for optimal distribution of existing pool of computing resources between composite applications and algorithm of utilization of resources on computing blocks. The purpose of the article is to analyze the results of simulation and mathematical modeling of the resource allocation process between composite applications, depending on the distribution option. Results The efficiency of existing dynamic planning algorithms that are related to the greedy algorithm class is considered. They find a locally optimal solution at each step. The boundary of effective planning of algorithms based on clustering approach is revealed. The efficiency of using ant colony optimization algorithm and algorithms of cluster approach using ant colony optimization algorithm is shown. The simulation of the distribution of the composite application is carried out, depending on the complexity of the graph construction. The dependence of the execution time of the composite application on utilization of resources on the calculated blocks is obtained. Using the resource utilization function, the quality of the distribution of composite application resources is analyzed, depending on the amount of data transferred to the calculations. Conclusions. Data on the quality of resource allocation is obtained, depending on such parameters as the time of implementation of the composite application, the volume of transmitted data, the complexity of the graph construction. A method for choosing the optimal resource allocation algorithm between composite applications depending on the listed parameters is proposed. This will allow you to quickly dispose of distributed computing blocks that are occupied by calculating a distributed task, which will speed up the computation of distributed tasks on an existing pool of computing blocks.
\end{abstract}

Keywords: composite application, utilization of resources, greedy algorithm, resource allocation, ant colony optimization algorithm, clusterization, ant clustering algorithm.

\section{Introduction}

We will evaluate the quality of the distribution of heterogeneous cloud environment resources between composite applications (CAs). To do this, using the methods and techniques of mathematical and simulation modeling, we will compare the results of the distribution of resources between the CAs.

During the experiment, it is necessary to take into account such parameters as the amount of transmitted CAs, the computational complexity, the construction of the CPs graph (the time of waiting for the tasks of the predecessors and their number). The presented parameters give an opportunity to clearly present the possibilities of developed methods for distributing resources of cloud environments between composite examples.

By comparison, methods for distributing resources are presented using the following algorithms: greedy, ant colony optimization, cluster and ant-cluster [1].

Greedy algorithm is a heuristic algorithm that takes the best decision, based on the available data at the current stage [9]. The essence of the greedy algorithm is locally optimal choice at each step.

The algorithm based on the clustering of computational tasks consists in partitioning the set of computational problems into a subset. These subsets are allocated to the computing resource, depending on the distribution requirements [11].

Ant colony optimization algorithm is one of the effective polynomial algorithms for finding approximate solutions of the salesman problem, as well as similar tasks for finding routes in graphs. The essence of the approach is to analyze and use the behavior model of ants who are looking for road from colony to food.

The ant clustering approach is an extended clustered algorithm using an ant. It means that a cluster of computational tasks, which are subject to allocation, will be considered as an ant.

Analysis of literature. The articles [2-10] discusses different approaches for allocating resources in infocommunication systems. In this case, a number of optimization algorithms are used, in particular, each of the proposed approaches is usually oriented to only one of the methods. The article [1] describes the possibility of a dynamic choice of optimization algorithm, which is oriented on the quality of distribution by a certain parameter. Therefore, there is a need to find out the quality of distribution of composite applications depending on optimization of the algorithm.

The purpose of the article is to analyze the results of simulation and mathematical modeling of the resource allocation process between composite applications, depending on the distribution option.

\section{Research results}

1. Comparison of the methods of distribution of resources of the CAs on time characteristics. One of the main characteristics of the implementation of a CAs on a plurality of computing blocks is the time at which the calculation of the task that was distributed is completed. Therefore, it is necessary to trace the dynamics of the time of execution of composite applications depending on the volume of transmitted data using the presented algorithms of distribution (Fig. 1-4). The simulation was carried out with a CA having 14-15 computing blocks.

In Fig. 1, we see the execution time of typical composite applications that have a data volume of 0 to $10 \mathrm{MB}$. It is clear the preference has the greedy algorithm at the small volumes of transmitted data. This is because the presented algorithm makes the optimal choice at each step of the allocation of resources, despite the rationality of the subsequent allocation. 

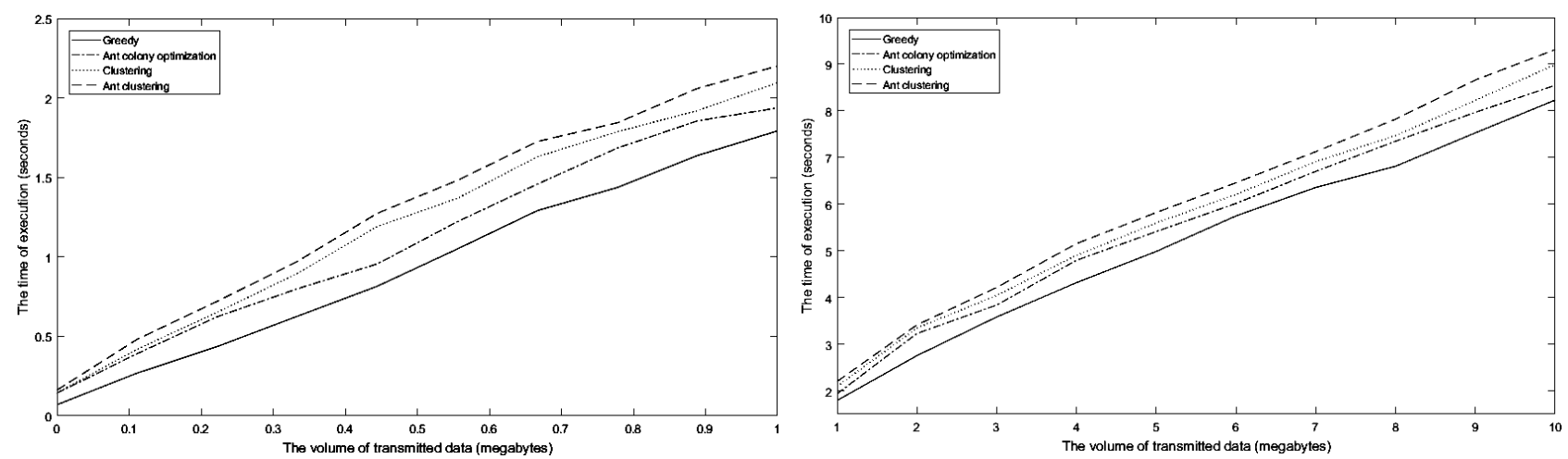

Fig. 1. Dependence of the time of execution of CAs from the allocation algorithm

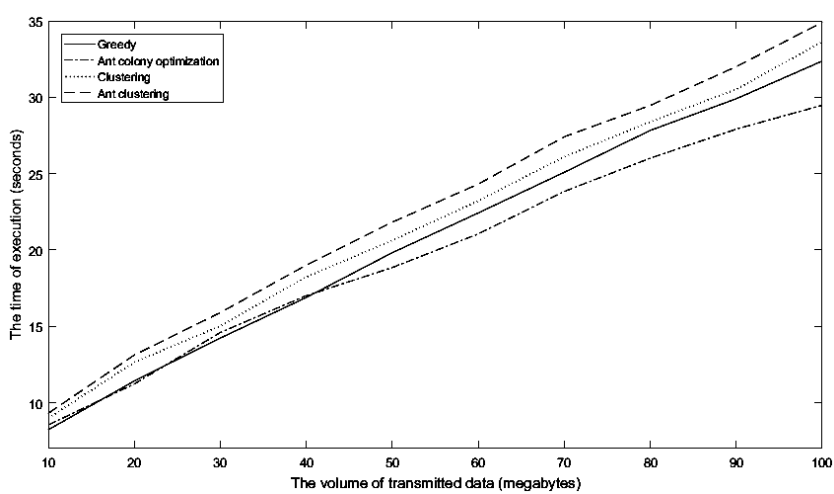

for the CAs with an increase in its volume. Improvement of allocation using an ant colony optimization algorithm is due to its ability to adapt to allocation conditions. But the complexity of its calculation did not give priority results on small volumes.

Fig. 3 represents the beginning of an efficient allocation of the resources of CAs with the help of cluster algorithm. This is facilitated by the possibility of grouping the tasks of CAs in terms of their parameters in the computing blocks.

Fig. 4 shows how the execution rate of a high data

Fig. 2. Dependence of the time of execution of CAs from the allocation algorithm array, distributed by cluster-ant algorithm, prevails over others.

Thanks to the presented figures, we can conclude

Fig. 2 represents loss of efficiency of greedy algorithm at the mark of $40 \mathrm{MB}$. This is due to an increase in the complexity of the allocation of resources which algorithm is more suitable for a typical model. This makes it possible to accelerate the execution of a $\mathrm{CA}$ on an existing pool of computing units.
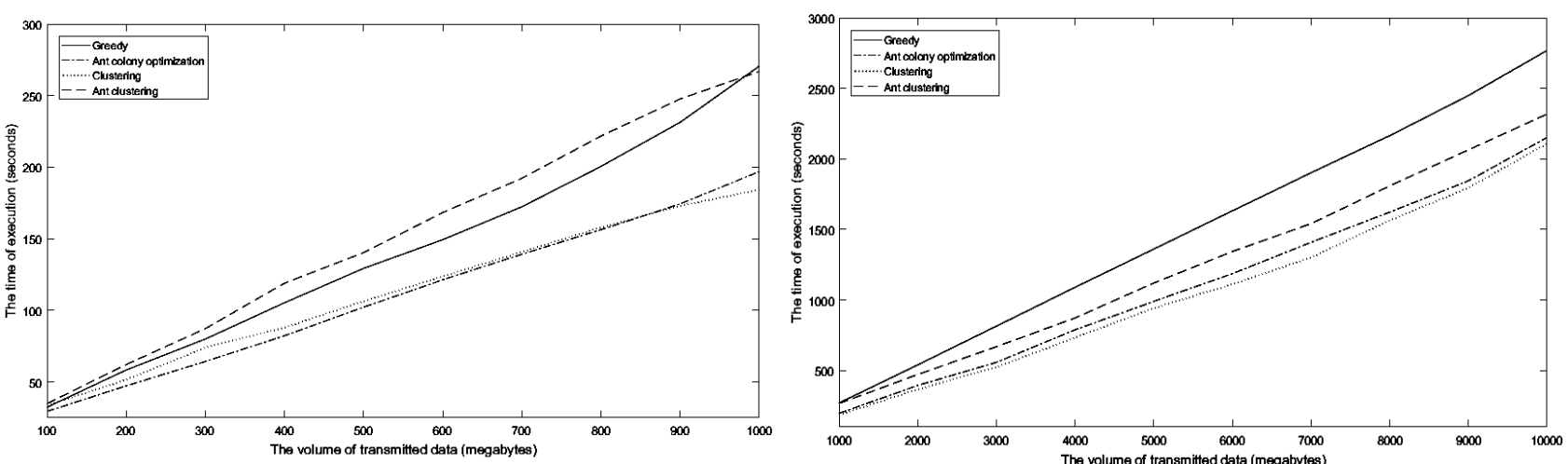

Fig. 3. Dependence of the time of execution of CAs from the allocation algorithm
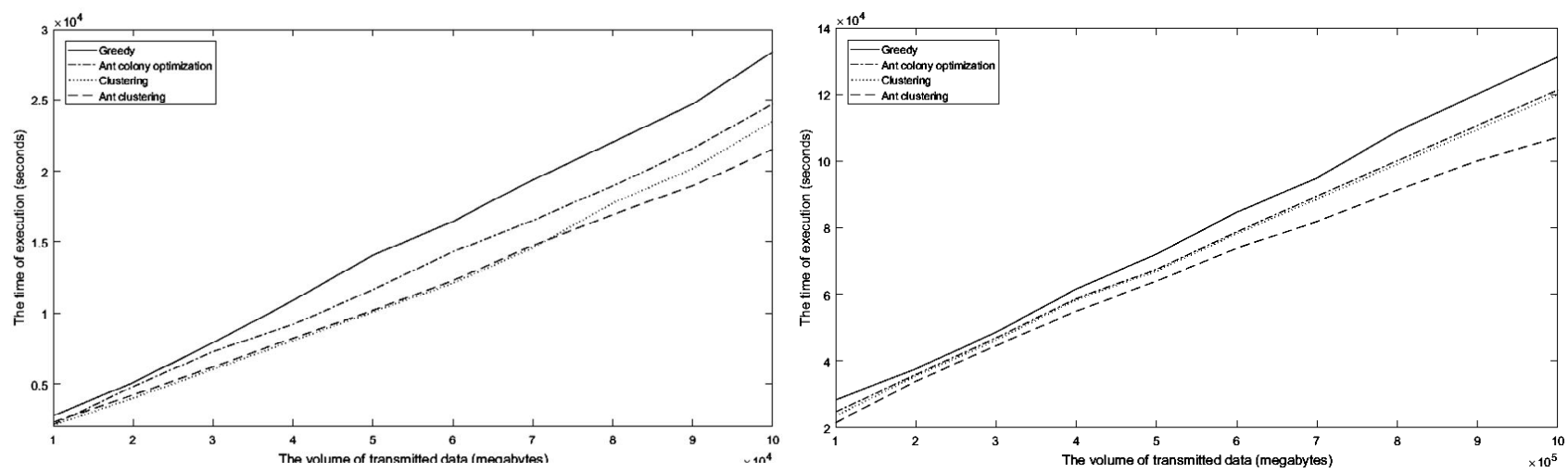

Fig. 4. Dependence of the time of execution of CAs from the allocation algorithm 
2. Comparison of methods of distribution of resources of CAs, depending on the complexity of the graph. Each CA consists of a number of computational tasks $\mathrm{DS}_{m n}$, which are represented by an acyclic graph [10]. Therefore, there is a need to take into account the influence of the complexity of the graph and its number of tasks for the implementation of the CA. To evaluate the quality of resource allocation, we use the resource utilization function. The dynamics of the distribution of resources is presented in Fig. 5, a.

With the presented data, we can conclude that the distribution efficiency varies depending on the

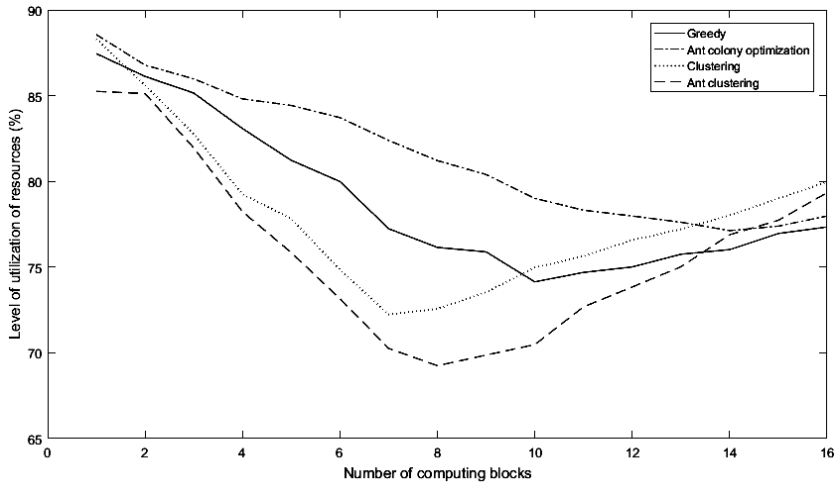

a

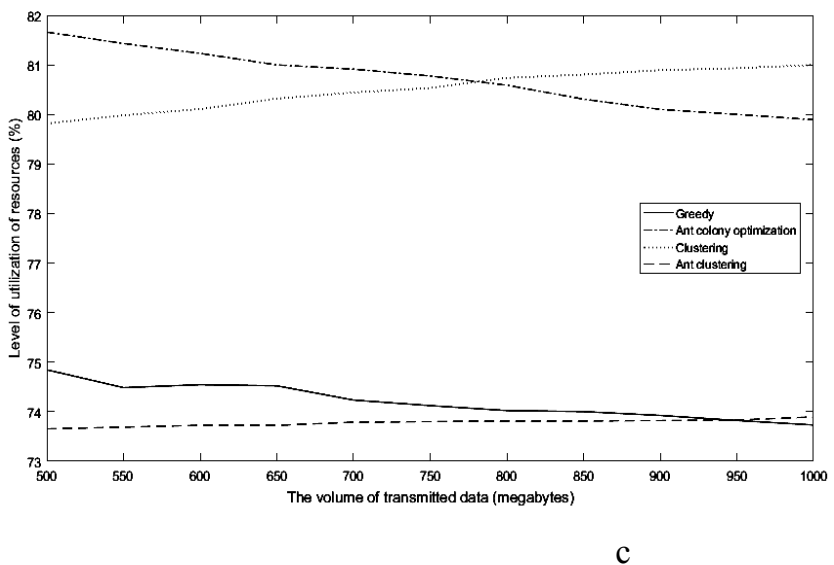

Fig. 5. The value of utilization of resources depending on:

$\mathrm{a}$ - the complexity of the graph of the Cas, b, c, d- the volume of the CA

On Fig. 5, b, c, d the value of utilization of resources varies on the boundaries of the change in the distribution of resources by different algorithms. This allows you to track the quality of resource allocation using the resource utilization feature.

\section{Conclusions}

The efficiency of existing dynamic planning algorithms that are related to the class of greedy algorithms is considered. The boundary of effective planning of algorithms based on clustering approach is revealed. complexity of the graph. Starting with 15 computing blocks, priority is given to such algorithms as cluster and ant-clustering.

3. Dependence of the level of utilization of $\mathbf{C A}$ resources depending on their volume. We will carry out demonstration the dynamics of change in the level of utilization of resources, depending on the volume of data of the breakaway data that are allocated. To do this, it was decided to monitor the change of utilization at the stages of changing the efficiency of the presented allocation algorithms in Fig. 5, b, c, d.
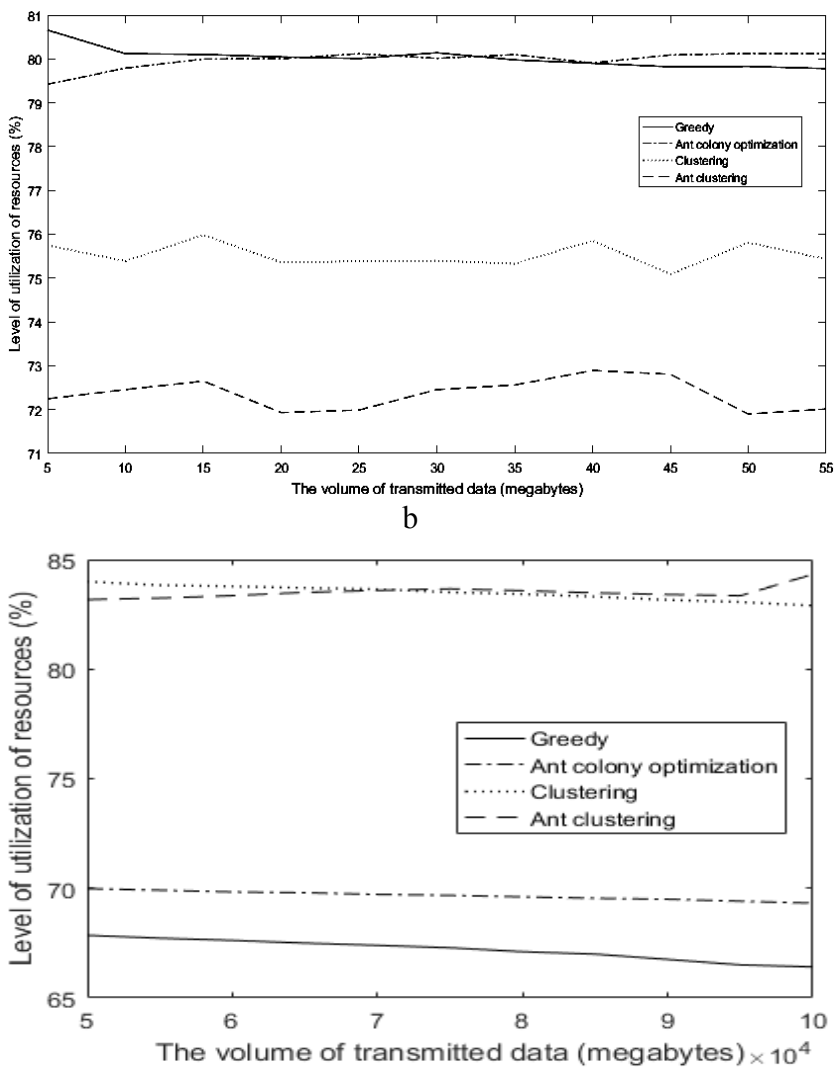

d
The efficiency of using ant colony optimization algorithm and algorithms of cluster approach using ant colony optimization algorithm is shown.

The simulation of the distribution of the composite application is carried out, depending on the complexity of the graph of its construction. The quality of the distribution of the resources of the $\mathrm{CA}$ is analyzed, depending on the amount of data transmitted using the resource utilization function.

Further research will be aimed at the development of a method for choosing the distribution algorithm of the CA based on its efficiency.

\section{REFERENCES}

1. Bulba, S.S., Davydov, V.V. and Kuchuk G.A. (2018), "Method for Resource Distribution between Composite Applications", Control, navigation and communication systems, PNTU, Poltava, No. 4 (50), pp. 99-104.

2. Lord P. and Goble C. (2005), "Seven Bottlenecks to Workflow Reuse and Repurposing Sattler", The Semantic Web - ISW 2005, pp. 323-337. 
3. Merlac, V., Smatkov, S., Kuchuk, N. and Nechausov A. (2018), "Resourses Distribution Method of University e-learning on the Hypercovergent platform", Conference Proceedings of 2018 IEEE 9th International Conference on Dependable Systems, Service and Technologies. DESSERT'2018, Ukraine, Kyiv, May 24-27, pp. 136-140.

4. Kuchuk, G., Kharchenko, V., Kovalenko, A., Ruchkov, E. (2016), “Approaches to Selection of Combinatorial Algorithm for Optimization in Network Traffic Control of Safety-Critical Systems", Proceeding of IEEE East-West Design \& Test Symposium (EWDTS'2016), pp. 384-389, available at: http://dx.doi.org/10.1109/EWDTS.2016.7807655 (last accessed on July 16, 2018).

5. Kuchuk, G., Nechausov, S., Kharchenko, V. (2015), "Two-stage optimization of resource allocation for hybrid cloud data store", International Conference on Information and Digital Technologies, pp. 266-271, available at: http://dx.doi.org/10.1109/DT.2015.7222982 (last accessed on July 16, 2018).

6. Kovalchuk S.V. and Bukhanovsky A.V. (2012), "Second Generation Cloud Computing: Composite Applications, Interactive Systems and Semantic Technologies", Infocommunication Technologies, Tarusa, available at: http://keepslide.com/technology/8702\#sthash. YHi3I5Gy.dpuf (last accessed on July 16, 2018).

7. Svyrydov, A., Kuchuk, H., Tsiapa, O. (2018), "Improving efficienty of image recognition process: Approach and case study", Proceedings of 2018 IEEE 9th International Conference on Dependable Systems, Services and Technologies, DESSERT 2018, pp. 593-597, available at: http://dx.doi.org/10.1109/DESSERT.2018.8409201 (last accessed on July 16, 2018).

8. Bulba, S.S. (2016), "Resource-oriented mathematical model of the basic network of a heterogeneous distributed system", Control, navigation and communication systems, PNTU, Poltava, No. 2 (38), pp. 73-75.

9. Dorigo, M., Di Caro G. \& Gambardella, L.M. (1999), “Ant Algorithms for Discrete Optimization”, Artificial Life, No. 5 (2), pp. 137-172.

10. Khaidukov D.S. (2009), Application of cluster analysis, MAKS Press, Moscow, 287 p.

Received (Надійшла) 28.07.2018 Accepted for publication (Прийнята до друку) 29.08.2018

Моделювання методів розподілу композитного застосунку

С. С. Бульба

Предметом розгляду виступають алгоритми оптимального розподілу існуючого пулу обчислювальних ресурсів між композитними застосунками та алгоритм утилізації ресурсів на обчислювальних блоках. Метою статті $\epsilon$ аналіз результатів імітаційного та математичного моделювання процесу розподілу ресурсів між композитними застосунками в залежності від варіанту розподілу. Результати. Розглянуто ефективність існуючих алгоритмів динамічного планування, які відносяться до класу жадібних алгоритмів. Вони знаходять на кожному кроці локально оптимальне рішення. Виявлена межа єфективного планування алгоритмів на базі кластеризаційнго підходу. Показано ефективність використання мурашиного алгоритму та алгоритмів кластерного підходу 3 використанням мурашиного алгоритму. Проведено моделювання розподілу композитного застосунку в залежності від складності графу його побудови. Отримано залежність часу виконання композитного застосунку від утилізації ресурсів на обчислених блоках. За допомогою функції утилізації ресурсів, проаналізовано якість розподілу ресурсів композитних застосунків в залежності від об’єму даних що передаються на обчислення. Висновки. Отримані дані, щодо якості розподілу ресурсів, в залежності від таких параметрів як: час виконання композитного застосунку, об'єм передаваємих даних, складність графу побудови. Запропоновано створення методу для вибору оптимального алгоритму розподілу ресурсів між композитними додатками, в залежності від перерахованих параметрів, на базі функції утилізації ресурсів. Це дасть змогу оперативно звільняти обчислювальні блоки гетерогенного середовища, які зайняті обчисленням розподіленої задачі, що пришвидшить обчислення розподілених задач на існуючому пулі обчислювальних блоків.

Ключові слова: композитний застосунок; утилізація ресурсів; жадібний алгоритм; розподіл ресурсів; мурашиний алгоритм; кластеризація; кластерно-мурашиний алгоритм.

\section{Моделирование методов распределения композитного приложения}

\section{С. С. Бульба}

Предметом рассмотрения выступают алгоритмы оптимального распределения существующего пула вычислительных ресурсов между композитными приложениями и алгоритм утилизации ресурсов на вычислительных блоках. Целью статьи является анализ результатов имитационного и математического моделирования процесса распределения ресурсов между композитными приложениями в зависимости от варианта распределения. Результаты. Рассмотрена эффективность существующих алгоритмов динамического планирования, которые относятся к классу жадных алгоритмов, которые находят на каждом шагу локально оптимальное решение. Обнаружен предел ефективного планирования алгоритмов на базе кластеризационного подхода. Показана эффективность использования муравьиного алгоритма и алгоритмов кластерного подхода с использованием муравьиного алгоритма. Проведено моделирование распределения композитного приложения в зависимости от сложности графу его построения. Получена зависимость времени выполнения композитного приложения от утилизации ресурсов на вычислительных блоках. С помощью функции утилизации ресурсов, проанализировано качество распределения ресурсов композитных приложений в зависимости от объема передаваемых данных на вычисления. Выводы. Полученные данные по качеству распределения ресурсов, в зависимости от таких параметров как: время выполнения композитного приложения, объем передаваемых данных, сложность графу построения. Предложено создание метода для выбора оптимального алгоритма распределения ресурсов между композитными приложениями, в зависимости от перечисленных параметров, на базе функции утилизации ресурсов. Это позволит оперативно освобождать вычислительные блоки гетерогенной среды, которые заняты вычислением распределенной задачи, что ускорит вычисления распределенных задач на существующем пуле вычислительных блоков.

Ключевые слова: композитное приложение; утилизация ресурсов; жадный алгоритм; распределение ресурсов; муравьиный алгоритм; кластеризация; кластерно-муравьиный алгоритм. 